\title{
16
}

\section{Marshalling a Pacific Response to Climate Change}

Nicollette Goulding

This chapter seeks to address the question: 'Are Pacific states marshalling a collective and cohesive Pacific response to climate change?' In doing so, it will examine how the expansion of the United Nations Framework Convention on Climate Change (UNFCCC) to include more interest areas, actors and alliances, has had an impact on Pacific cohesion. Firstly, it will examine how the splitting and subsequent division of Pacific states into various issue areas has led them to engage in new affiliations known as climate clubs, alternative forums and alliances; secondly, it will assess the efforts of regional institutions in facilitating a more coordinated Pacific response to climate change at the international level.

\section{Fragmentation in the Climate Change Regime and Pacific Cohesion}

The shift in the global climate change regime from policy-making to actual implementation of actions has resulted in the creation of new areas which are causing a 'spreading out' of interests of Pacific states. From the establishment of the Kyoto Protocol in 1997, the agenda of the UNFCCC has shifted from one of policy formation to that of implementation (Shibuya 2004), and as such there is an emerging trend for the establishment of state clubs whose members are drawn 
together by commonalities. Engberg-Pedersen (2011) argues that sector-based groupings are more conducive to reaching agreements, as the number of actors is reduced and the issue areas more focused. This shift towards implementation has also seen a shift in the influence of traditional institutions, such as the Alliance of Small Island States (AOSIS) (Shibuya 2004) as countries begin to focus on the implementation of actions to best suit their national needs.

Faced with conflicting national priorities, Pacific states are increasingly choosing to speak and make individual submissions and interventions within the UNFCCC negotiation process. This trend is shown in Figure 16.1 for the period, 20062011, with Fiji, Republic of the Marshall Islands (RMI), Federated States of Micronesia (FSM), Papua New Guinea (PNG), Samoa, Solomon Islands, Tuvalu, and Vanuatu choosing to make separate submissions outside of their AOSIS coalition. This shift in the actions of Pacific nations coincides with the shift in the UNFCCC process from discussions and negotiations to implementation and actions - a more 'sectoral approach' to dealing with climate change issues. This clearly shows that the shift in the UNFCCC process affects the movement or shift in how Pacific Island Countries (PICs) engage in climate change negotiations.

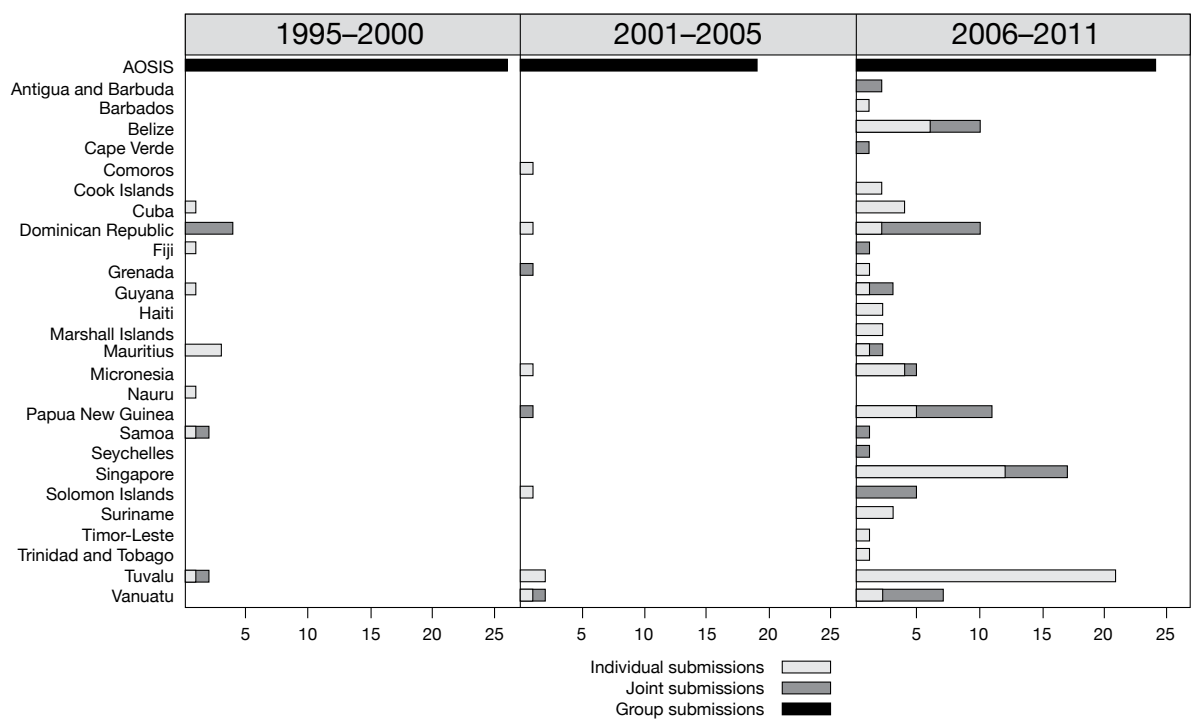

Figure 16.1: Count of AOSIS and AOSIS members submissions, 2006-2011

Source: Author's research.

Coalitions are formed on the basis of mutual interest and compromise, however, when individual members can no longer see their interests adequately reflected in the common position, they may choose to leave the coalition 
(Betzold et al. 2011) or seek other coalitions to fill the gaps and better address their needs. As processes in the UNFCCC shift towards implementation and a sector-based approach, Pacific cohesion is becoming tested as PICs become increasingly more active in areas that appeal to their own national agenda as opposed to a common regional agenda. Despite being established as the core institution for climate change, the UNFCCC has increasingly been deemed a mechanism for goal setting and not implementation. This has led to the proliferation of sector-based clubs (Widerberg and Stenson 2013), which leads to further fragmentation. This fragmentation has had a rippling effect, causing fragmentation to Pacific cohesion, and creating uncertainty and panic as PICs look to the horizon for new partnerships as the deadline to an agreement to succeed the Kyoto Protocol looms nearer in 2015.

A particularly contentious subject on which PICs have not reached consensus is the mechanism of REDD+ (Reducing Emissions from Deforestation and Forest Degradation) an incentive that provides payment for actions that prevent the loss and destruction of forested areas. AOSIS and Pacific solidarity on this issue was first tested in the mid-1990s, when the negotiating bloc of JUSCANZ (Japan, United States, Canada, Australia and New Zealand), led by New Zealand and Australia, attempted to obtain the support of Melanesian States (Fiji, PNG, Vanuatu, and Solomon Islands) on the issues of land use, land use change and forestry (Barnett and Campbell 2010). Although this would have had benefits for the Melanesian states, they instead chose to maintain their solidarity on this occasion with their fellow PICs and the AOSIS coalition (Barnett and Campbell 2010). This stance could be attributed to the 'Pacific Way' - a term that was coined by Fiji's first Prime Minister, Ratu Sir Kamisese Mara, which is synonymous with consensus, and usually refers to shared ideas about solidarity and reciprocity, and the fostering and maintenance of kinship networks.

However, with growing recognition and interest in REDD+ within the UNFCCC process, the interest of PICs who can benefit from this mechanism has also increased. Only the large volcanic islands with vast forest cover - PNG, Solomon Islands, and Fiji — stand to gain, as opposed to low lying atolls, such as Kiribati, Tuvalu and RMI, who have no forest cover and therefore nothing to gain from this initiative (Boydell 2008). The Melanesian countries' decision to sign up to the REDD+ Partnership is a step that goes against the grain of Pacific solidarity and the 'Pacific Way', where consensus is usually the order of the day. Tuvalu and PNG have been the most vocal, locking horns over this issue. This was quite visible at UNFCCC COP (UNFCCC Conference of the Parties, the annual global conference to negotiate climate change policy and targets) in Copenhagen in 2009, where tensions over REDD+ led to PNG breaking ranks with AOSIS (Ryan 2010). Both Fiji and Tuvalu have invested a great deal of time and resources on this issue, making 18 and 16 interventions respectively on the 
topic of REDD+ between 2007 and 2009 (see Figure 16.2). Given the long list of issues on the agenda at UNFCCC conferences, and taking into account PICs' limited resources and capacity, even when pooled together, it is particularly interesting to note that certain countries are investing much of their limited resources and capacities on issues such as REDD+ where there are contrasting views between certain Pacific states. This points to the fact that the coalition of AOSIS cannot be used as a vehicle to drive this issue and, as a result, some states are opting to pursue the issue individually or with a select few in the group that have similar vested interests. Given the capacity constraints, these resources could be better used in lobbying for other substantive shared issues, such as adaptation, mitigation, and climate financing.

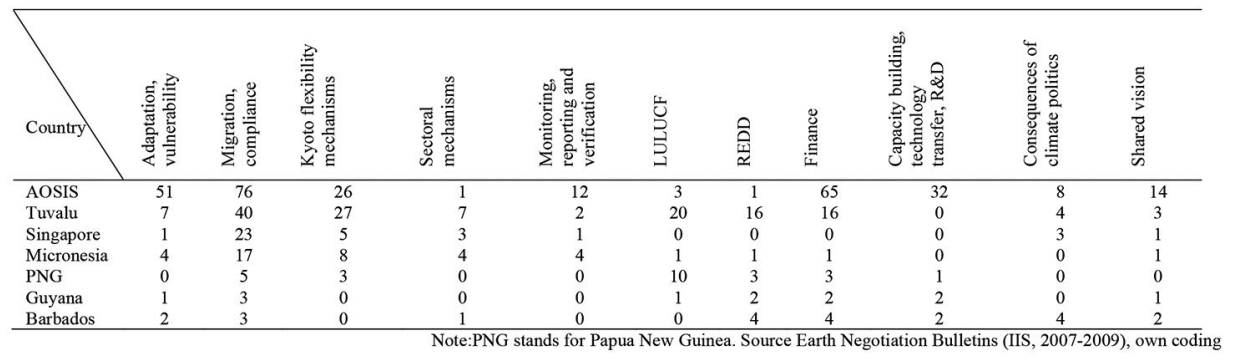

Figure 16.2: Topics of interventions by AOSIS countries between 2007-2009

Source: Betzold et al. (2011).

Growing dissatisfaction with the sub-optimal progress in the overall UNFCCC negotiations has seen a swing towards the forming of new alliances (both formal and informal). Several Pacific Island states have joined climate change forums that run parallel to the established UNFCCC process. Described as the thousand flowers blooming' (Maybe et al. 2013), the increase in the numbers and types of climate clubs has created paths for states to pursue their interests (see Figure 16.3). A majority of these clubs' objectives work in tandem with the objectives of the UNFCCC (Bailer 2012), and thereby provide a means for Pacific Island states to caucus strategically in order to better serve their national interests. Overall, these clubs fill the governance gaps and allow like-minded states to garner support and use available opportunities to advocate their national climate change needs. As Bo Kjellen, former chief UNFCCC negotiator for Sweden, said regarding such clubs: 'Only when national conditions are favourable for an agreement, can an international agreement be met' (Eritsland 2013). Some of the Pacific Island states are actively forming new alliances and engaging in forums such as Cartagena Dialogue, Global Bio-Energy Partnership, Coalition of Forested Nations, REDD+ Partnership, Renewable Energy and Energy Efficiency Partnership, and the MRV and International Partnership. 


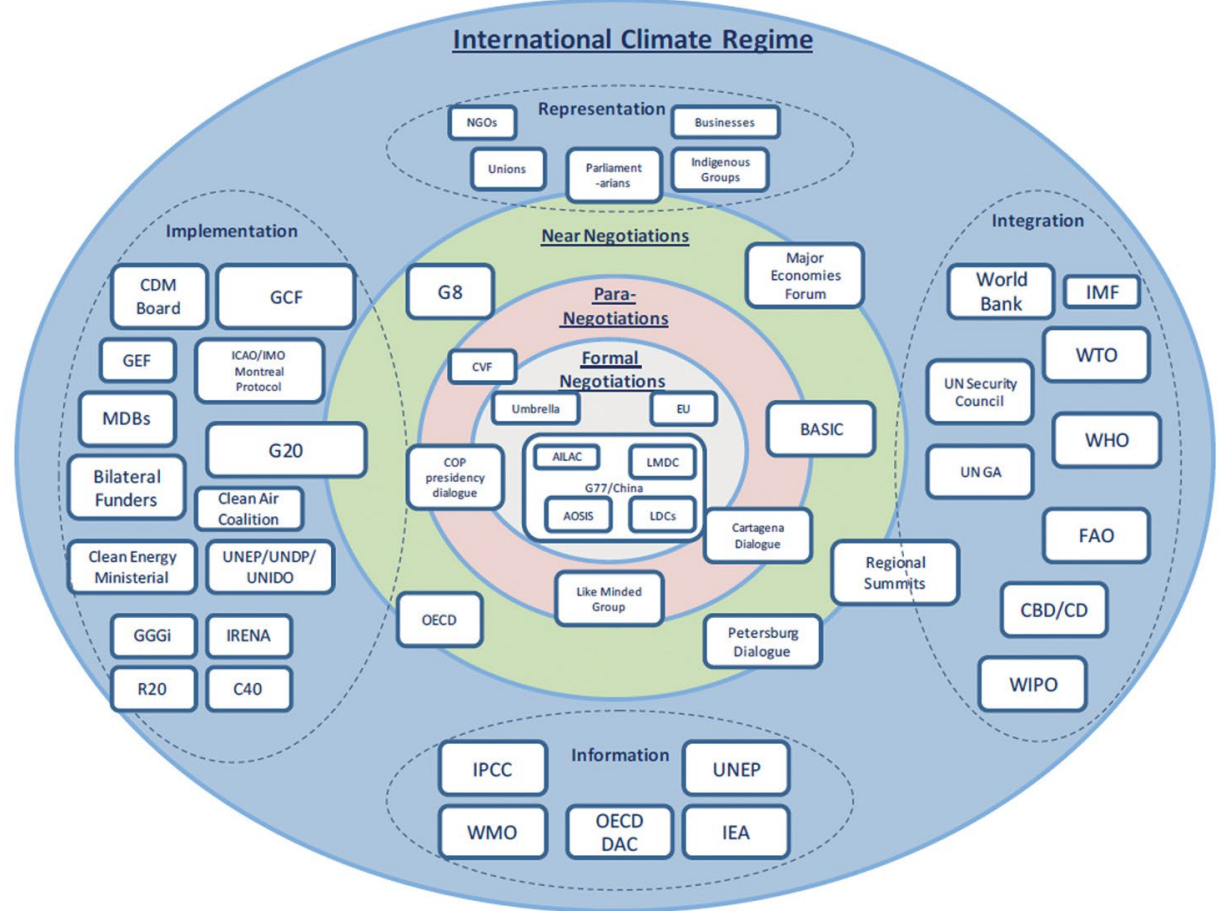

Figure 16.3: A near-comprehensive illustration of the many climate clubs, groupings and actors in the climate change regime, described as the 'thousand flowers blooming'

Source: Maybe et al. (2013).

With the growing frustration over the deadlock in UNFCCC negotiations on mitigation targets, countries are increasingly finding alternative forums through which they can articulate their priorities with other like-minded states. The Climate Vulnerable Forum, initiated in 2009, is such a forum, consisting of a partnership of states that are considered the most vulnerable to climate change impacts. The members of this forum are not only vulnerable states, but also developed nations from Africa, Asia, the Americas and PICs - Kiribati, Tuvalu, and Vanuatu. When Kiribati hosted the forum in 2010, Solomon Islands, Tonga, and the Marshall Islands also participated.

The Cartagena Dialogue for Progressive Action - described as a progressive dialogue for furthering the climate change debate - is another new alliance that has developed as an alternative forum. The forum, which consists of developing and developed states from across the traditional negotiating alliances, allows members to openly express and discuss their national interests in a safe space (Maybe et al. 2013). Seizing the opportunity to move beyond the deadlock in the UNFCCC, Samoa and Marshall Islands are the lone Pacific countries participating in the dialogue. Though this dialogue group does not negotiate together within 
the UNFCCC, they do develop a joint position. (Maybe et al. 2011). Motivation to join such an alternative alliance is best articulated by Marshall Islands Foreign Affairs Minister, Tony de Brum, who said: 'We don't restrict our climate change efforts to the UNFCCC, and we think that's good practice because you never know what might happen' (Tong 2013). As national interests and uncertainty become the dominant narratives of the climate change discussions, Pacific states are increasingly having to engage in these new forums and clubs as individuals or smaller subsets, limiting their links with each other, as is shown in Figure 16.4.

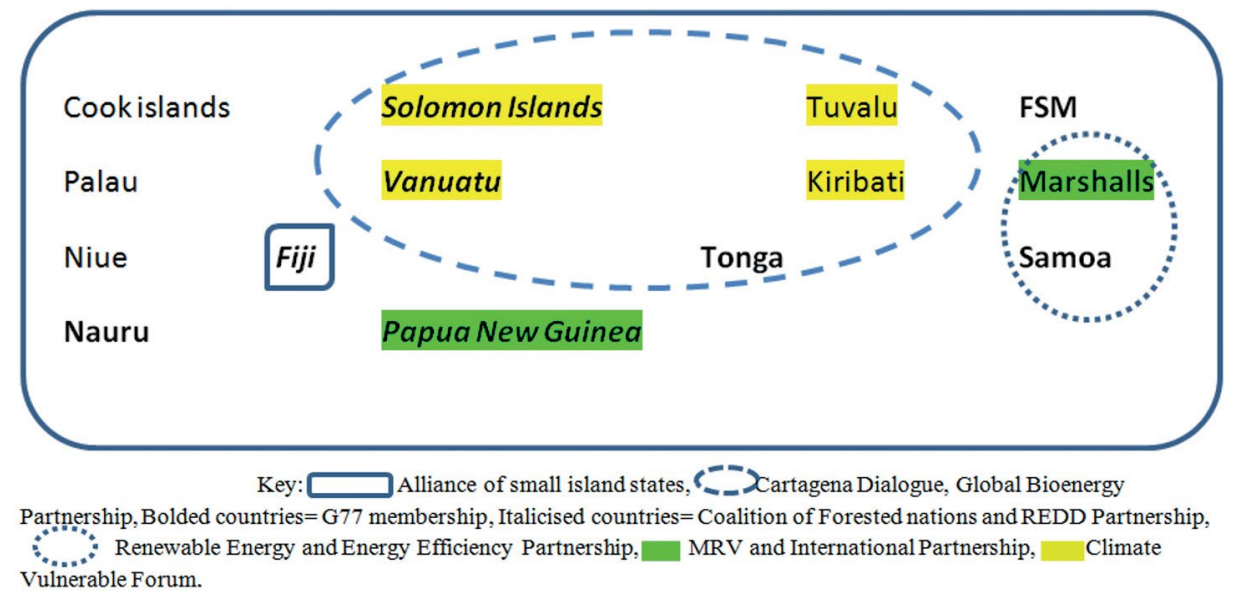

Figure 16.4: The alliances, climate clubs and outside forums in which PICs participate

Source: Author's research.

Apart from participating in these informal spaces, Pacific states are also trying to engage in debates on climate change outside of the UNFCCC, and in certain cases this has led to greater cohesion. According to Keohane and Victor (2011), because of diversity and uncertainty in the problems of climate change, states have difficulty in seeing linkages between different alliances and areas within the UNFCCC process. Within the United Nations, PIC cohesion has been revitalised by the creation of the Pacific Small Island Developing States (PSIDS) grouping which caucuses over issues pertaining to sustainable development and climate change (Tarte 2014). As a result of this grouping, the united voice has been more audible in COP events in Cancun, Durban and Doha. It is also the case that since the formation of this grouping there has been better coordination between the various traditional alliances to which each of these PICs are party. Given the important roles that PICs are playing in major alliances, such as Fiji role as chair of the G77 plus China, Nauru as the chair of AOSIS, and Tuvalu playing a significant role within the Least Developed Country (LDC) grouping, it would appear that PICs are increasingly working cohesively and finding common ground within these alliances. However, the very fact that coordination 
resulted outside of the UNFCCC suggests that Pacific states find it difficult to come together within the UNFCCC. As RMI Foreign Affairs Minister Tony de Brum stated: 'Small Pacific states sometimes find other avenues much easier to engage with, because of the practical and psychological barriers to accessing the United Nations talks' (ABC News 2014).

In the pursuit of achieving their individual country agendas, PICs are forging new alliances and their active participation in these climate clubs, aside from affecting Pacific cohesion, could have other serious implications. One such implication is that of 'forum shopping'. As defined by Eritsland (2012), forum shopping is 'the strategic selection of favourable venues from a menu of alternative governance arrangements, but also withdrawal from old and creation of new arrangements'. As these forums and alliances are relatively new, they rarely contain established rules of conduct. This could lead to uneven power dynamics, resulting in larger states negatively influencing and unfairly dominating priorities and diluting the focus interest of the smaller states. This was evident, for example, when Australia pulled out of the Cartagena Dialogue in 2013 as a change in government resulted in a change in its climate policy.

These new developments could also endanger the central role that the UNFCCC plays in establishing a legally binding agreement that includes all developed and developing nations, as countries may choose to continue working within alternative groups that better suit their interests. This may lead to less ambitious emission targets than would have otherwise been achieved had the UNFCCC remained the central forum for debate. There is a need to not only draw links between these new extensions, but to recognise the increasing role that these structures may have in furthering or detracting from the main debate. Amongst other possible solutions, this may involve states reporting developments in these forums to the UNFCCC. However, with all states, particularly small Pacific states, already overwhelmed with reporting to the UNFCCC on existing issues, this process may need a regional solution.

\section{Coordinating a Pacific Response}

As the PSIDS make attempts to bridge their relations at the international level, regional efforts to feed into this process are equally important for Pacific cohesion on the climate change agenda. As stated by President Anote Tong (2012): As we focus our attention on our relations beyond our region, we need also to look at how we relate with each other within our region. There can be no doubt that there is greater strength in regional solidarity.' Since the introduction of the climate change issue to the Pacific region at the Pacific Forum leaders meeting 
held in Rarotonga in 1991, the Pacific Islands Forum (PIF) was charged with regional coordination of efforts to help PICs to find solutions to combat and cope with the negative effects of climate change. Under the theme 'Environmental Issues', and in later years under 'Climate Change', this has been an agenda item in the annual leaders' communiqué.

In 2005, at the Pacific Islands Forum in PNG, the Pacific leaders agreed on developing the Pacific Plan as a framework for strengthening regional cooperation and integration. The Pacific Plan has since undergone a major review and been replaced by the Framework for Pacific Regionalism. The framework is intended to support focused political conversations and settlements that address key strategic issues, including shared sovereignty, pooling of resources, and delegation of decision-making. Rather than providing a list of regional priorities, it seeks to set out a robust process through which regional priorities will be identified and implemented.

The annual leaders' communique is essentially a to-do list for the region to implement. The communique drives the actions, and the vehicles for the implementation of these actions are the Council of Regional Organisations in the Pacific (CROP) organisations, which have their own governing councils, and the Pacific Islands states themselves, through their national plans and strategies. Since 2010, these actions have largely focused on strengthening access to, and management of, climate change financial resources for member countries. The emphasis has been on accessing international climate change financing and facilitating improved management of these resources at the national level.

The issue of climate change has gained deep and wide traction within Pacific societies. National governments, non-state actors, regional and inter-regional bodies, schools, and businesses have ramped up the rhetoric for advocacy. The rhetoric has touched the hearts of the leaders and this is reflected in their adoption of the Majuro Declaration for Climate Leadership on 5 September 2013. In a concise and focused way, the declaration captures the Pacific's political commitment to be a region of climate leaders and to spark a 'new wave of climate leadership' that can deliver a safe climate future for all. In this declaration, Pacific leaders (with the exception of Fiji, which was suspended from the forum in 2009 and has not yet rejoined, despite it meeting the criteria for doing so) are committed to take on the role of climate leaders for Pacific Island Forum states in a bid to set targets for the reduction of greenhouse gas emissions. However, as has been seen in previous forum communiqués, there can sometimes be a disconnect in the messages coming from the forum leaders at a regional level and their actions at the international level. For example, in the lead up to the development of the Kyoto Protocol in 1997, the Pacific lobbied at an international level for targets to reduce emissions. However, in the same year, 
the Pacific Islands Forum leaders statement was toned down to non-committal language - 'recognition of climate change impacts' — and urged participants to be forthcoming on emissions targets.

The watering down of the communique text on climate change points to the immense influence that Australia and New Zealand have on forum outcomes, diluting the Pacific's message on climate change. Regional efforts on climate have been greatly hampered by Australia's insensitivity to Pacific concerns. At the 2009 Pacific Islands Forum leaders meeting, the following comments were made by Seni Nabou, a leading Fijian advocate for climate change:

The Forum Communiqué comes as a slap in the face for the Pacific leaders who went into the PIF calling for 45 per cent cuts in greenhouse pollution by 2020 . Today they leave agreeing to 50 per cent cuts by 2050. They went in with a strong position that global warming needs to be kept below 1.5 degrees, and finished up agreeing to 2 degrees (Rowell 2009).

This occurred because of the leaders buckling to pressure by Australia. Speaking at the RMI's mission in New York in September 2014, Foreign Affairs Minister Tony de Brum said that he and leaders of other PICs were bewildered by 'backsliding' on climate change by Australia, whom the region considers as a 'big brother down south'. This was a response to the Abbott Government's abolition of the carbon tax, and defunding of scientific and advisory bodies for climate change research. Minister de Brum said that PICs felt abandoned in light of this back-pedalling, especially after they had all come together and supported Australia's successful bid for a seat on the Security Council.

The process detailed below shows that the forum leaders' communiqué reflects the regional climate change position that was arrived at after extensive discussions. The Secretary General of the Pacific Islands Forum Secretariat holds the permanent chair of CROP, as mandated by leaders in 1995 and reaffirmed in 2004. The CROP executives meeting, which is attended by the CEOs and heads of CROP organisations, occurs annually, biannually, or when the need arises to discuss pertinent regional issues - climate change is one such issue. The outcomes from these meetings are gathered with the outcomes of other regional ministerial meetings, councils, committees and working groups and are consolidated at the Forum Officials Committee meeting (the governing council of the Pacific Islands Forum Secretariat, which is made up of representatives from member governments who are tasked with oversight of the secretariat's activities) where recommendations on climate change matters are submitted as an agenda item for consideration by the leaders. A climate change position or directions on further climate policy development, implementation or reporting could form part of the leaders' communiqué which reports on the decisions at the leaders retreat. However, with growing criticism rising over the interference 
of Australia and New Zealand, it is questionable whether the PIF will still be regarded as a forum representing the interests of the Pacific on the climate change issue.

While the PIF is the pre-eminent authority in coordinating the climate change issue, the Secretariat of the South Pacific Regional Environmental Programme (SPREP) is mandated to take the lead on environmental issues. Established as an independent intergovernmental organisation in 1992, SPREP is the Pacific's central agency responsible for regional climate change policy, programmes and projects. SPREP's role in coordinating a Pacific response to climate change is broad-ranging. Apart from providing assistance to its 20 member states, including representation at international meetings and coordinating the Pacific Climate Change Roundtable (PCCR), it also serves as a conduit for disbursement of climate change funding to PICs, disseminates information on climate change, and implements climate change projects in the region (Barnett and Campbell 2010).

There is however, some criticism of SPREP's preoccupation with implementing adaptation actions in the region at the expense of creating Pacific cohesion in global negotiations (Barnett and Campbell 2010). The need for the Pacific to work together towards common goals within AOSIS in COP processes is fundamental, as is overcoming limited capacity and skills to effectively negotiate against developed nations. This is a point stressed by the Director General of SPREP, David Sheppard, at the SPREP preparatory meeting in the lead up to the COP in Durban. In reality, SPREP's role extends only as far as the provision of advisory services and limited capacity development for UNFCCC negotiations, and responding to the needs of countries on a request basis. It does not extend to aiding Pacific states to find a joint negotiation position.

Being an issue of regional concern, climate change seems to find its way onto the agendas of most regional and sub-regional forums. For example, as diplomacy between Melanesian Spearhead Group (MSG) member states intensifies, so too have discussions of climate change, to the point that, in 2012, the MSG met to develop its own position on global climate change negotiations (Tarte 2014). This was done in part to acknowledge that they needed to hash out differences that could cause divisions between them. This points to an alternative important step towards building a coherent and cohesive Pacific position to the UNFCCC. MSG actions may have shown the way a broader Pacific might arrive at a unified stance on climate change - by thrashing out sub-regional differences and ultimately coming to an amicable decision.

The Pacific Islands Development Forum (PIDF) has been touted as the institution that will further enhance the development of cohesion in Pacific joint positions on issues regarding sustainable development and climate change. The notable 
absence of Australia and New Zealand from PIDF is said to better encourage the traditional 'Pacific Way' of consultation and discussion (Tarte 2014). With its agenda focusing on areas such as green growth, its impact may primarily be on implementation within the region. Its inclusiveness of governments, civil society, CROP agencies, development partners, and the private sector provides the potential for Pacific states to enhance linkages between themselves.

As the climate change issue evolves, understanding the implications of overlapping alliances will be central if Pacific states want to continue the momentum from PSIDS efforts. This may require further engagement with nongovernmental and civil society groups, and the networks that they can provide. For example, Tuvalu's links with the organisation 350.org demonstrates how engagement with such organisations can bring positive attention to a country's cause. Such affiliations can allow for the formation of partnerships that could allow Pacific states to better engage with each other at various levels and in different forms - such as youth groups, private sector, NGOs, etc.

\section{Conclusion}

'Consultation and consensus' (Tarte 2014) is the epitome of the 'Pacific Way' of diplomacy. When threatened by the impacts of climate change, Pacific states responded in a similar way to previous times of crisis - they banded together and formed alliances with similarly vulnerable states in order to increase their ability to appeal to global states' sense of morality against the common challenge of 'climate change'.

Climate change is not a single problem, but rather a plethora of intertwined challenges with unique 'attributes, administrative challenges and distinctive political constituencies' mingled with a host of diverse interests from various states and non-state actors (Keohane and Victor 2011).

Perhaps the bottom line for tackling the climate change problem is aptly described by Tony de Brum: 'Climate Diplomacy is most effective when you are able to speak to someone else about his or her political and national interests.' (de Brum 2014). Such effectiveness however may come at the cost of Pacific cohesion. With the impact of climate change beginning to batter their island homes, it is not surprising that Pacific states should want to take advantage of every possible opportunity, even if it means doing so without their traditional Pacific allies.

The climate change debate, however, is not limited to the UNFCCC. When PICs are not contesting the debate within the UNFCCC, they are finding themselves on the frontline of other battles in informal and formal spaces outside the UNFCCC. 
Stalemates within the UNFCCC, such as occurred with the highly controversial Copenhagen Accord, are becoming too common an occurrence. Dissatisfaction with the UNFCCC process is leading states to pull away or join parallel forums. These new arenas are becoming potentially better alternatives for furthering the climate change debate in a manner which is less divisive, more open to actors' self-interests, and progressive enough to allow for experimentation in alternative solutions (Fuhr et al. 2011). Desperate for a globally binding agreement by 2015, PICs are engaging in these alternative forums and forging new alliances to help build momentum toward this goal.

Enhanced Pacific coordination in forums such as PSIDS in the UN underscores the inability of Pacific states to achieve the same within the UNFCCC via AOSIS. Regional efforts to improve Pacific coordination within the UNFCCC process appear to be limited by several factors. The interference of New Zealand and Australia, and the focus on capacity development and regional implementation actions in the PIF and SPREP, prevent adequate opportunities to coordinate a Pacific response to climate change. However, with recent leadership and initiative shown by the MSG in attempting to discuss differences between themselves, and the development of the PIDF, there are indicators that there is some recognition of the need to develop a better coordinated Pacific response. It is glaringly apparent, however, that at present there is no means to develop a Pacific position in climate change negotiations leading up to Paris 2015.

Climate change vulnerability is high on the agenda of all Pacific states. It cannot, however, be ignored that the complexity and fragmentation of the UNFCCC is having obvious implications for PIC cohesion as PICs break out into various clubs in a desperate attempt to tackle different aspects of the climate change issue. With the growing literature on the impact of UNFCCC fragmentation pointing out that this may lead to more effective climate change actions, including better avenues for achieving long term emissions reduction, the question that needs to be answered is: 'Is Pacific cohesion really necessary to achieve a global commitment to climate change action that addresses Pacific interests and priorities?'

\section{References}

ABC News, 2014, 'Marshall Islands Minister Unsure of Australia's Stance on Climate Change'. Available at: www.abc.net.au/news/2014-04-01/anmarshall-islands-urges-urges-australia-to-take-22leadership/5360510. 
Bailer, S., 2012, Bargaining Resources and Strategies in Climate Change Negotiations, Swiss Network of International Studies, Zurich. Available at: www.snis.ch/system/files/4_bailer_-_bargaining_resources_and_strategies_ in_climate_ch_0.pdf.

Barnett, J. and J. Campbell, 2010, Climate Change and Small Island States: Power, knowledge and the South Pacific, Earthscan, London.

Betzold, C., P. Castro and F. Weiler, 2011, AOSIS in the UNFCCC Negotiations: From unity to fragmentation, Centre for Comparative and International Studies, Zurich.

Boydell, E., 2008, 'A Different Divide?: Pacific Island countries and north-south agendas in the evolution of global climate policy', Cross-sections: The Bruce Hall Academic Journal 4.

de Brum, T., 2014, 'Climate Diplomacy: A perspective from the Marshall Islands', Climate Diplomacy, 29 September. Available at: www.climate-diplomacy.org/ news/climate-diplomacy---perspective-marshall-islands.

Engburg-Pedersen, L., 2011. 'Climate Change Negotiations and their Implications for International Development Cooperation', Danish Institute for International Studies. Available at: um.dk/en/ /media/UM/English-site/ Documents/Danida/Partners/Research-Org/Research-studies/Climate $\% 20$ change $\% 20$ negotiations $\% 20$ and $\% 20$ their $\% 20$ implications $\% 20$ for $\% 20$ international $\% 20$ development $\% 20$ cooperation $\% 202011$.pdf.

Eritsland, S., 2012, 'Fragmented Systems for Collective Action: Can the institutional architecture in East Asia carry the challenge of climate change?', unpublished MA thesis, Universitetet i Oslo, Oslo.

Fuhr, L., B. UnmuBig, H.J.H. Verlome and F. Yamin, 2011. A Future for International Climate Politics: Durban and beyond, Heinrich Böll Foundation, Berlin.

Keohane, R.O. and D.G. Victor, 2011, 'The Regime Complex for Climate Change', The Harvard Project on International Climate Agreements Discussion Paper 10-33. Available at: belfercenter.ksg.harvard.edu/files/Keohane_ Victor_Final_2.pdf.

Maybe, N., L . Gallagher and C. Born, 2013, Understanding Climate Diplomacy: Building diplomatic capacity and systems to avoid dangerous climate change, Third Generation Environmentalism, London. 
Rowell, A., 2009, 'Copenhagen: Australia accused of selling-out Pacific Islands', Oil Change International, 7 August. Available at: priceofoil.org/2009/08/07/ copenhagen-australia-accused-of-selling-out-pacific-islands/.

Ryan, Y., 2010, 'COP 15 and Pacific Island States: A collective voice on climate change', Pacific Journalism Review 16(1), pp. 192-203.

Shibuya, E., 2004, 'The Problems and Potential of the Pacific Islands Forum', in J. Rolfe (ed.) The Asia-Pacific: A region in transition, Asia-Pacific Center for Security Studies, Honolulu, pp. 102-15.

Tarte, S., 2014, 'Regionalism and Changing Regional Order in the Pacific Islands', Asia and the Pacific Policy Studies 1(2), pp. 312-24.

Tong, B.A., 2012, 'Keynote Address', launch of the Pacific International Relations Forum of the School of Government, Development and International Affairs of the University of the South Pacific, 9 October. Available at: pidp. eastwestcenter.org/pireport/2012/October/10-11-sp.htm.

Tong, D., 2013, 'The Man Behind Majuro: Minister Tony de Brum', Climate Tracker. Available at: adoptanegotiator.org/the-man-behind-majurominister-tony-de-brum/.

Widerberg, O. and D.E. Stenson, 2013, 'Climate Clubs and the UNFCCC', FORES Study 2013:3, Fores, Stockholm. 
This text is taken from The New Pacific Diplomacy, edited by Greg Fry and Sandra Tarte, published 2015 by ANU Press, The Australian National University, Canberra, Australia. 